The University of San Francisco

USF Scholarship: a digital repository @ Gleeson Library |

Geschke Center

Philosophy

College of Arts and Sciences

2001

\title{
The Instability of the Standard Justification for Physician-Assisted Suicide
}

Thomas A. Cavanaugh

University of San Francisco, cavanaught@usfca.edu

Follow this and additional works at: http://repository.usfca.edu/phil

Part of the Philosophy Commons

\section{Recommended Citation}

Cavanaugh, Thomas A., "The Instability of the Standard Justification for Physician-Assisted Suicide" (2001). Philosophy. Paper 20. http://repository.usfca.edu/phil/20

This Article is brought to you for free and open access by the College of Arts and Sciences at USF Scholarship: a digital repository @ Gleeson Library | Geschke Center. It has been accepted for inclusion in Philosophy by an authorized administrator of USF Scholarship: a digital repository @ Gleeson

Library $\mid$ Geschke Center. For more information, please contact repository@usfca.edu. 


\title{
The Instability of the Standard Justification for Physician-Assisted Suicide
}

\author{
THOMAS A. CAVANAUGH
}

Proponents commonly justify the legalization of physician-assisted suicide (PAS) in terms of a patient's wanting to die (autonomy) and the patient's having a medically established good reason for suicide. ${ }^{1-4}$ These are the common elements of the standard justification offered for the legalization of PAS. In what follows, I argue that these two conditions exist in significant tension with one another, operating according to distinct dynamics that render the justification for PAS an unstable "let it be so" basis for public policy. Moreover, no natural connection keeps these two criteria united. Indeed-as I argue - the two elements of the justification oppose and threaten to exclude one another. Thus, the PAS justification is too labile a basis for sound public policy.

\section{The PAS Justification: \\ The Simple Version}

Those who justify PAS distinguish between good and bad reasons for PAS. The proposed good reasons are either an imminently terminal illness or an incurable progressively debilitating disease, such as multiple sclerosis. ${ }^{5}$ Other reasons, for example, clinically treatable depression ${ }^{6}$ or pain resulting from inadequate palliative measures ${ }^{7}$ are regarded as unacceptable. The proposed good reasons are medical and objective. Thus, a physician could establish that the patient actually does have a good reason. The good reason, however, is not proposed as the only condition that must be met. In accordance with the principle of autonomy, a patient must also really-clearheadedly, consistently, and persistently-want to kill himself. ${ }^{8}$ If a patient wants to kill himself and he has a good reason to kill himself, then, according to the standard justification, his physician legally ought to be able to assist him by providing him with a lethal drug.

\section{The Complex Version: The Motive Requirement}

The standard justification is, however, slightly more complicated. For, according to the standard justification, it is not sufficient that the patient have a good reason to kill himself and that he want to kill himself, he must also want to kill himself for the good reason. Thus, his autonomy is subordinated to the good reason. This may be called the "motive requirement." The standard justification clearly incorporates the motive requirement. The standard justification has safeguards to prevent patients from killing themselves for bad reasons. ${ }^{9}$

For example, the following passage from the Oregon Act illustrates the presence of the motive requirement:

If in the opinion of the attending physician or the consulting physician a patient may be suffering from a psy- 
chiatric or psychological disorder, or depression causing impaired judgment, either physician shall refer the patient for counseling. No medication to end a patient's life in a humane and dignified manner shall be prescribed until the person performing the counseling determines that the person is not suffering from a psychiatric or psychological disorder, or depression. ${ }^{10}$

Clearly, the Oregon Act rules out depression as an acceptable basis for PAS. Again, in the Oregon Act, witnesses attest that:

[T] he person signing this request [the patient requesting PAS]: appears to be of sound mind and not under duress, fraud, or undue influence. ${ }^{11}$

The Oregon Act would not justify a patient's pursuing PAS if her reason for doing so was to mollify a husband or child tired of caring for her, or because she understood herself to be a burden to her loved ones.

The BANEC guidelines also incorporate the motive requirement:

The primary physician has ascertained the following... 2... the patient is mentally competent and not suffering from a depression that impairs decision-making capability. ... 4 . To the best of the physician's knowledge, the patient's choice to hasten death has been freely made, independent of finances, family, health care workers, health insurance, or other coercion. ${ }^{12}$

Another proposed justification mandates that:

[T] he physician must ensure that the patient's suffering and the request are not the result of inadequate comfort care.... The presence of depression is relevant if it is distorting rational decision making and is reversible in a way that would substantially alter the situation. Expert psychiatric evaluation should be sought when the primary physician is inexperienced in the diagnosis and treatment of depression, or when there is uncertainty about the rationality of the request or the presence of a reversible mental disorder the treatment of which would substantially change the patient's perception of his or her condition. ${ }^{13}$

With varying degrees of precision and detail, the proposed justifications for PAS each incorporate the motive requirement by ruling out certain motives as unacceptable, leaving an imminently terminal illness or an intractable chronically debilitating disease as the sole acceptable motives for PAS.

What difference does the motive requirement make? Examples illustrate its import. If some patient had terminal cancer and wanted to die for some other, unacceptable reason-for example, because he was clinically depressed, or because his family wanted him to die-then the standard justification justifies neither his suicide nor others' assistance. For, although he wants to kill himself and he has a good reason to kill himself, he does not want to kill himself for the right reason. Of course, advocates of PAS could tutor him to want to kill himself for the right reason. Nonetheless, that they would have so to instruct him indicates that they could not justify assisting him, at least not according to the standard justification.

Thus, the justifications propose that PAS is justified if and only if the patient wants to die for a medically substantiated good reason.

\section{The Problem of Asymmetry}

In what follows, I reflect on the elements of the standard justification in order to determine what unites them. To do this, I contrast the standard justification with the justification offered 
by soft-paternalists, who maintain that a patient's really wanting to die is a sufficient reason for him to kill himself and a sufficient reason for a physician to assist him. Thus, the softpaternalist proposes autonomy as sufficient to justify PAS. ${ }^{14}$

Those employing the standard justification do not accept autonomy as sufficient to justify PAS. Yet, by rejecting the soft-paternalist's account, those who rely on the standard justification have difficulty justifying their position concerning those who have medically established good reasons for killing themselves but who do not want to kill themselves. By examining such cases, it becomes clear that the two elements of the standard justification do not have any intrinsic link uniting them.

Consider the justification the softpaternalist would offer for a patient who does not pursue PAS because he does not want to die. The soft-paternalist's position would be that the patient's really not wanting to die itself justifies him in not killing himself and justifies others in not convincing him to kill himself. This position is exactly symmetrical with the soft-paternalist's justification for PAS: autonomy is itself a justification for pursuing what the patient really wants, regardless of his reasons for wanting it. Indeed, the exactness of the symmetry between the soft-paternalist's justification for a patient's killing or not killing himselfand for a physician's assisting or not assisting-indicates a strength of the soft-paternalist's position. Moreover, the soft-paternalist's response concerning why we ought not to assist or convince a patient to kill himself who does not want to kill himself - "he really does not want to kill himself" - would be enough for most to justify not assisting or convincing him to kill himself. (Of course, this is not to argue for PAS justified in terms of soft-paternalism; it is only to note that soft-paternalism does not suffer, as the standard justification does, from the problem of asymmetry.)

Those who propose the standard justification hold, along with the softpaternalist, that a patient's not wanting to kill himself justifies both his not killing himself and others' not assisting him. This response, however, indicates a problematic asymmetry in the standard justification. The standard justification requires a medically established reason for killing oneself and for assisting another to kill himself; it thereby subordinates the patient's selfdetermination to a medically established good reason. Other reasons, for example, being lonely or depressed, are not acceptable. Yet, if the patient who wants to kill himself is not to kill himself nor to be assisted either because he lacks a good reason, or because, although he has a good reason, he wants to kill himself for an unacceptable reason, then what about those who have medically established good reasons for killing themselves but who do not want to kill themselves? According to the standard justification, if a patient has a good reason to die but does not want to die, he is not to be assisted nor instructed that he ought to kill himself. Why is his autonomy not subordinated to his good reason for killing himself? How does the standard justification justify his not killing himself and others' not instructing him of the good reason he has for killing himself?

Of course, most will agree that such a patient ought not to kill himself if he does not want to and that others ought not to assist him or to instruct him to kill himself. Nonetheless, in terms of the standard justification, what grounds one's response to such a case? For, if the autonomy of a patient who wants to kill himself but lacks a good reason is not sufficient to justify his suicide 
or a physician's assistance, why is it sufficient to justify not assisting or instructing those who have good reasons to kill themselves but who do not want to kill themselves? Moreover, if the autonomy of a patient who wants to die and who has a good reason to die must be subordinated to his good reason such that he must want to kill himself for the good reason that he has - and not for an unacceptable reason - then why is autonomy not subordinated to a good reason when a patient has a good reason? What accounts for this asymmetry in the standard justification?

\section{Responses to the Asymmetry Problem}

In response to the asymmetry objection, the advocate of the standard justification could argue that such patients must have good countervailing reasons for wanting to live that outweigh the good reasons they have for wanting to die. Yet, if one concedes-as advocates of the standard justification do-that some people who want to kill themselves do not have good reasons, then why think that there are not also people who do not want to kill themselves but who do not have good reasons for not killing themselves? It is reasonable to think that there must be patients who, according to the standard justification, have overall good reasons for killing themselves but who do not want to kill themselves. What about these patients?

The proponent of the standard justification could argue that more is required for a patient to justify killing himself than is required for a patient to justify not killing himself. This is the argument that one ought to err, as it were, on the side of life, rather than on the side of death. It is better, or so this argument proposes, to have more unjustified lives than unjustified deaths.
This line of argument, however, inclines away from legalizing PAS. Following this line of reasoning, one would erect legal barriers against homicide, such as current laws outlawing suicideassistance, the very laws that advocates of PAS wish to change.

The advocate of the standard justification could refer to what is generally agreed to: it is wrong to kill another against his will. Yet, homicidal selfdefense, surely the most widely accepted and least controversial case of legally and ethically justified homicide, almost always involves killing an assailant against his will. Moreover, even if an assailant did want to be killed, that fact would not be relied on in a legal or moral justification for killing him. Homicide in self-defense is justified without reliance on-indeed, usually in opposition to-the autonomy of the one killed. Such homicides are justified entirely in terms of the killer having a good reason for killing: in order to preserve harmless human life. Thus, the advocates of the standard justification must explain how they can assert both that a person has what they consider a good reason for killing himself (e.g., an imminently terminal illness) and that it would be wrong to assist him or to instruct him to commit suicide because he does not want to. For, as seen in the justification of homicidal self-defense, a justification that incorporates good reasons inclines awayeven entirely away-from regard for what the one killed wants, relying on the good reasons as sufficient to justify killing.

In response to the charge of asymmetry, the advocate of the standard justification could simply stipulate that in order for a patient to kill himselfand for a physician to assist him - it is necessary, but not sufficient, that he want to kill himself. Thus, a patient's not wanting to kill himself would suffice to justify his not killing himself 
and others' not assisting or instructing him, just as his not having a good reason for suicide, or his having a good reason but wanting to kill himself for a bad reason, suffices for rejecting his request for assistance. The proponent of the standard justification could maintain that such a stipulation is enough given that we are considering public policy; that is, something that often is nothing but a "let it be so." For example, we drive on one side of the road rather than another by mere fiat. The decision is entirely arbitrary. Nonetheless, it works. Traffic laws are broken, but they are not broken because they are arbitrary. The same holds true for many other matters of public policy that repose ultimately on a publicly agreed upon "let it be so." Why would the case of PAS differ? Why can it not rest ultimately on public fiat or merely on the fact that sometimes we do not accept autonomy as a sufficient reason for honoring a patient's request and sometimes we do?

Perhaps the laws and public policy regarding PAS could repose on a practice that holds that autonomy and a medically established good reason are not sufficient to justify PAS independently of one another. Yet, there are good reasons for thinking that the dynamics of these criteria will separate them in practice. That is, as I argue in what follows, given the independent character of these two elements taken separately, neither fiat nor custom offer a sound basis for the legalization of PAS.

\section{The Directions of Pull of Autonomy and Good Reasons}

Autonomy and a medically established good reason pull in different directions. The soft-paternalist illustrates the dynamic of autonomy: as long as the patient really wants to kill herself and does not harm others by killing herself, then her suicide and others' assistance of her suicide are justified, regardless of her objective medical reasons or lack of reasons altogether. The pull of autonomy would have suicide and suicide-assistance grounded entirely in the will unfettered by reason, to be furthered as long as no one else is harmed.

In opposition to the pull of autonomy, the dynamic of a good reason-illustrated in the justification of homicidal self-defense-is indifferent to what the one killed wants, focusing entirely on the good reason for homicide. This latter justification attends to what is objective and serves as a good reason for anyone, regardless of what they want. A good reason for me to kill an assailant will be a good reason for you or anyone to kill that or any other relevantly similar assailant. Although it is fanciful, the good reason for killing the assailant will be a good reason for the assailant to kill himself. For example, if a Dr. Jekyll/Mr. Hyde personality were to exist and as Dr. Jekyll knew that he would become a homicidal Mr. Hyde, then, following the logic of a good reason, Dr. Jekyll ought to kill himself in order to prevent himself as Mr. Hyde from killing harmless human life. Because of their objective character, good reasons subordinate an individual's wants and desires to themselves. Moreover, there is nothing in the logic of a good-reason-based justification that prohibits taking life without the consent of the one whose life is taken.

That the most widely accepted legal and moral justification for homicideself-defense-has no regard for the wishes of the one killed ought to make society hesitant to establish medical conditions as good reasons for killing oneself and as good reasons for assisting another's suicide. For, following the dynamic of a good-reason-based justification, the medical good reason offered by the advocates of PAS is inclined toward functioning indepen- 
dently of a patient's autonomy as a sufficient justification for suicide and suicide-assistance.

In the arena of PAS, specifically how would the dynamic of a good reason operate independently of and in opposition to autonomy? Take, for example, the distinction, offered by those who rely on the standard justification, between a good and a bad reason. As noted, this distinction partially undermines the autonomy of a patient who may want to kill himself for a reason that is not accepted as good. Moreover, by maintaining that a patient must have a good reason for killing himself in order to be assisted, by assisting some to kill themselves, physicians publicly state that certain patients have good reasons for killing themselves. Physicians thereby imply that patients relevantly similar to those other patients also have good reasons for killing themselves. Thus, the autonomy of patients who are similar but for their not wanting to kill themselves to those who have been assisted is jeopardized. In fact, the better the reason that those who were assisted had for killing themselves - and, thereby, the better the reason physicians had for assisting them - the more unreasonable relevantly similar individuals who do not want to kill themselves would be if they persist in not wanting to kill themselves. Thus, the objective character of a good-reason-based justification threatens autonomy by either rejecting the reasons that a patient has for killing himself or by implying that, although they do not want to kill themselves, some patients have good reasons for killing themselves and, to that extent, ought to kill themselves.

In conclusion, I have presented the opposed dynamics of the two elements of the standard justification. I have sought the nexus between these two elements that unites them to form a functioning unit with its own dy- namic. I find no link other than the assertion that they are to be kept together. Given the lack of a significant internal connection and the intrinsic energies of these two elements as they operate independently of and in opposition to one another, I find the standard justification highly labile and an unsound basis for sound public policy.

\section{Notes}

1. The Oregon Death with Dignity Act, or Measure 16.

2. Heilig S, Brody R, Marcus F, Shavelson L, Sussman P. Physician-hastened death: advisory guidelines for the San Francisco Bay area from the Bay Area Network of Ethics Committees. Western Journal of Medicine 1997;166:370-8.

3. Baron C, Bergstresser C, Brock D, et al. A model state act to authorize and regulate physician-assisted suicide. Harvard Journal on Legislation 1996;33:1-34.

4. Quill T, Cassel C, Meier D. Care of the hopelessly ill: potential clinical criteria for physician-assisted suicide. New England Journal of Medicine 1992;327:1380-4.

5. In the Oregon Death with Dignity Act (note 1) and the Bay Area Network's advisory guidelines (note 2), the patient must have a terminal illness with a prognosis of death within six months. In the model state act proposed by Baron et al. (note 3 ) and the clinical criteria proposed by Quill et al. (note 4 ), the patient may have either a terminal illness or an incurable progressively debilitating disease such as multiple sclerosis.

6. That clinical depression is excluded as a bad reason for resorting to PAS can be seen from, for example, the Oregon Death with Dignity Act, (note 1): "If in the opinion of the attending physician or the consulting physician a patient may be suffering from a psychiatric or psychological disorder, or depression causing impaired judgment, either physician shall refer the patient for counseling. No medication to end a patient's life in a humane and dignified manner shall be prescribed until the person performing the counseling determines that the person is not suffering from a psychiatric or psychological disorder, or depression causing impaired judgment" (from section 3.03 on Counseling Referral). A similar exclusion can be found in Baron et al. (note 3), Section 3.(a)(3): "The patient 


\section{Perspectives}

has made a request of the responsible physician to provide medical means of suicide, which request $(\mathrm{A})$ is not the result of a distortion of the patient's judgment due to clinical depression or any other mental illness."

7. See, for example, note 4, Quill et al. 1992:1382: "[T]he physician must ensure that the patient's suffering and the request are not the result of inadequate comfort care."

8. See, for example, note 4, Quill et al. 1992:1382; note 3, Baron et al. 1996: section 3.(a)(3)(D); and note 1, the Oregon Act, section 3.06.

9. The justifications also have safeguards to prevent others from assisting the patient for bad reasons, but I will not attend to this aspect of the standard justification.

10. See note 1, Oregon Act, section 3.03.

11. See note 1, Oregon Act, section 6.01 .

12. See note 2, Heilig et al., 1997: 372, V. A. 1-4.

13. See note 4, Quill et al., 1992:1382.

14. Feinberg, J. Harm to Self. London/New York: Oxford University Press, 1986:351-62. Softpaternalism is the position that one may temporarily prevent another from harming himself in order to determine that he knows what he is doing and desires to do it. Once one has made this determination, then one allows him to pursue his goal unimpeded. 